\title{
PERBEDAAN BERPIKIR KRITIS MAHASISWA PENDIDIKAN BIOLOGI YANG PROSES PEMBELAJARANNYA MENGGUNAKAN E-LEARNING DAN KONVENSIONAL
}

\author{
Liah Badriah $^{1)}$, Dani Ramdani ${ }^{1)}$, Suharsono ${ }^{1)}$ \\ ${ }^{1}$ Jurusan Pedidikan Biologi Fakultas Keguruan dan Ilmu Pendidikan \\ Universitas Siliwangi Tasikmalaya \\ J1. Siliwangi No. 24 Kota Tasikmalaya 46115 \\ Email: liahbadriah014@gmail.com
}

\begin{abstract}
This study aimed to determine the difference of critical thinking ability of biology students whose learning process using e-learning and conventional learning based on the concept of ecosystem. This study uses used is the comparative method with the population of all biology students of first semester with the samples taken are class $1 \mathrm{~A}$ and $1 \mathrm{C}$ which each of 30 people and the sample taken by cluster random sampling technique. . In addition, technique of collecting the data was conducted by giving the posttest to the students in order to obtain the data about students' final learning outcomes and applying rubric for the sake of identifying the students' critical thinking abilities. Data analysis technique used is test of difference of two mean (t-test) with significant level $(\alpha)=5 \%$ using SPSS 21 for Windows. Based on the data analysis and hypothesis testing, the value sig. (2 tailed) is $0,83>0,05$ for critical thinking ability, based of resut analyze that there was a not significant learning outcome and critical thinking ability of Biology students employing e-learning and conventional learning.
\end{abstract}

Key Words: E-learning, conventional learning, critical thinking ability

\begin{abstract}
ABSTRAK
Penelitian ini bertujuan untuk mengetahui perbedaan berfikir kritis mahasiswa yang proses pembelajarannya menggunakan pembelajaran e-learning dan konvensional pada konsep ekosistem. Metode yang digunakan adalah metode komparatif dengan populasi seluruh mahasiswa biologi semester satu dengan sampel yang diambil adalah kelas 1A dan 1C yang masing-masing sebanyak 30 orang dan sampel diambil dengan teknik cluster random sampling. Pengambilan data dilakukan dengan memberikan soal essay untuk memperoleh data kemampuan berfikir kritis mahasiswa. Teknik analisis data yang digunakan adalah uji perbedaan dua rata-rata (uji-t) dengan taraf signifikan $(\alpha)=5 \%$ menggunakan SPSS 21 for Windows. Berdasarkan analisis data dan pengujian hipotesis menunjukan nilai sig.(2 tailed) sebesar 0, $83>0,05$ sehingga dapat disimpulkan Ho diterima artinya tidak ada perbedaan yang signifikan hasil belajar mahasiswa biologi yang proses pembelajarannya menggunakan model pembelajaran elearning dan konvensional.
\end{abstract}

Kata kunci : E-learning, konvensional, berfikir kritis 
PENDAHULUAN

Perkembangan pendidikan dari abad 19 sampai sekarang mengalami perkembangan yang signifikan, dimulai dari penggunaaan fasilitas belajar mengajar yang sederhana smapai di temukannnya teknologi. Kehadiran Teknologi Informasi dan Komunikasi (TIK) dalam pembelajaran merupakan tantangan tersendiri bagi dunia pendidikan. Tuntutan dalam globalisasi, pendidikan telah hadir di depan mata. Berbagai perangkat komputer beserta koneksinya dapat menghantarkan peseta didik secara cepat dan akurat apabila dimanfaatkan secara benar dan tepat. Teknologi menyediakan berbagai alternatif yang dapat digunakan untuk menyampaikan materi kepada peserta didik. Penggunaan media yang disediakan teknologi informasi merupakan salah satu usaha pengembangan kualitas pendidikan.

Menurut Purbowo (2002:1) "Pendidikan merupakan suatu proses komunikasi dan transfer informasi dari pendidik kepada peserta didik yang berisi informasi pendidikan, yang memiliki unsur pendidikan sebagai sumber informasi, sebagai media sarana penyampaian ide, gagasan, materi pendidikan serta peserta didik itu sendiri.

Keberhasilan seorang pendidik tidak terbatas pada pencapain hasil belajar saja namun sekarang peserta didik diharuskan memiliki kemampuan berfikir tingkat tinggi (High Order Thinking) salah satu diantaranya dalam peningkatan kemampuan berfikir kritis. Keberhasilan peningkatan kemampuan berfikir kritis ini sangat dipengaruhi oleh variasi pembelajaran yang bersifat konvebsional atau bahkan modern. Oleh sebab itu penulis mencoba menerapkan pembelajaran konvensional dengan metode ceramah dan diskusi dan dibandingkan dengan pembelajaran berbasis e-learning dengan menggunakan website. E-learning merupakan kegiatan pembelajaran yang memanfaatkan jaringan (internet, $L A N, \quad W A N$ ) sebagai metode penyampaian, interaksi, dan fasilitasi serta didukung oleh berbagai bentuk layanan belajar lainnya.

Berdasarkan hasil observasi yang telah dilakukuan pada mahasiswa program studi pendidikan biologi tingkat I semester 1 ditemukan permasalahan dalam kegiatan pembelajaran dikelas pada konsep ekosistem dengan rata-rata mahasiswa kurang begitu mampu dalam mengembangkan kemampuan berpikir kritis serta penguasaan konsepnya pun belum begitu memuaskan dengan perolehan nilai pada konsep tersebut.

\section{TUJUAN}

Target yang hendak dicapai dalam kegiatan ini adalah

1. mengetahui perbedaan kemampuan berfikir kritis mahasiswa pendidikan biologi yang proses pembelajarannya 
menggunakan e-learning dan konvensional.

2. mengembangkan alternatif metode pembelajaran berbasis website.

3. mengimplementasi pembelajaran berbasis website sebagai alternatif pilihan pembelajaran.

\section{LUARAN}

Luaran yang dihasilkan dalam kegiatan ini adalah :

1. diketahuinya perbedaan kemampuan berfikir kritis mahasiswa biologi yang proses pembelajarannya menggunakan e-learning dan konvensional.

2. Dikembangkannya alternatif metode pembelajaran berbasis website.

3. Diimplementasikannya pembelajaran berbasis website sebagai alternatif pilihan pembalajaran.

\section{METODOLOGI}

Metode yang digunakan dalam penelitian ini adalah metode komparatif dan pendekatan kuantitatif. penelitian komparatif adalah sejenis penelitian deskriptif yang ingin mencari jawaban secara mendasar tentang sebab-akibat, dengan menganalisis faktor-faktor penyebab terjadinya ataupun munculnya suatu fenomena tertentu (Nazir: 2005).

\section{Variabel Penelitian}

Dalam penelitian yang ini, yang menjadi variabelnya adalah : a. Kemampuan berfikir kritis mahasiswa (Y1) sebagai variabel terikat.

b. Pembelajaran e-learning dan konvensional (X) sebagai variabel bebas.

\section{Desain Penelitian}

Dalam penelitian ini, disain penelitian yang digunakan adalah postest one group desain, peneliti mengadakan treatment dua kali yang diperkirakan sudah mempunyai pengaruh kemudian diadakan post test. Adapun disain penelitian menurut Arikunto, Suharsimi (2006:85) yaitu:

rancangan : kelas eksperimen I :

$\begin{array}{llr} & \mathrm{R} X \mathrm{O} \\ & \text { kelas kontrol II : } \\ & \mathrm{R} \quad \mathrm{O} & \\ \text { prosedur : } & \text { subjek diberi } \\ & \text { perlakuan } \mathrm{X} \text { dan } \\ & \text { setelah dilakukan } \\ & \text { pengukuran } \quad(\mathrm{O}) \\ & \text { sebagai akibat dari } \\ & \text { perlakuan yang } \\ & \text { diberikan }\end{array}$

keterangan:

$\mathrm{R}$ : Random

$\mathrm{X}$ : perlakuan (treatment) pertama dengan menggunaka pembelajaran e-learning

$\mathrm{O}$ : pencapaian kelompok sampel setelah perlakuan untuk kemampuan berfikir kritis

\section{Teknik Pengumpulan Data}

Pengumpulan data dilakukan dengan menggunakan tes individual dalam bentuk soal Essay yang diberikan setelah proses belajar mengajar selesai. 


\section{Analisis Data}

Teknik analisis data yang dilakukan adalah analisis komparatif. Analisis deskriptif dilakukan dengan menyajikan data penelitian yang berupa deskripsi data analisis komparatif digunakan untuk menguji hipotesis.

Sebelum analsis hipotesis dilakukan, maka diperlukan pengujian beberapa persyaratan yang harus dipenuhi. Persyaratan analisis yang harus di penuhi adalah :

a. Uji normalitas data, menggunakan pengujian Kolmogorov-Smirnov dengan kriteria jika nilai asymp. Sig (p) $>\alpha$, maka sebaran data berdistribusi normal.

b. Uji Homogenitas. Uji Homogenitas digunakan sebagai bahan acuan untuk menentukan keputusan uji statistik. Adapun dasar pengambilan keputusan dalam uji homogenitas adalah :
1) Jika nilai signifikansi $<0,05$, maka dikatakan bahwa varian dari dua atau lebih kelompok populasi data adalah tidak sama.

2) Jika nilai signifikansi $>0,05$, maka dikatakan bahwa varian dari dua atau lebih kelompok populasi data adalah sama.

\section{HASIL DAN PEMBAHASAN}

Data kemampuan berpikir kritis mahasiswa biologi yang pembelajarannya menggunakan pendekatan induktif diperoleh dengan menggunakan rubrik penilaian berpikir kritis yang penilainyya dilakukan saat pembelajaran berlangsung yang terdiri dari 4 indikator. Berdasarkan indikator dan penilaian yang tersedia dalam rubrik maka diperoleh data yang terlampir yang tersaji dalam Tabel 1.

Tabel 1. Ringkasan penghitungan hasil belajar

\begin{tabular}{l|r|r|r|r|r}
\hline & $\mathrm{N}$ & \multicolumn{1}{|c|}{ Mean } & $\begin{array}{c}\text { Std. } \\
\text { Deviation }\end{array}$ & Minimum & Maximum \\
\hline Kelas A & 30 & 10.0167 & 3.06955 & 4.00 & 15.00 \\
Kelas C & 30 & 9.8500 & 2.96284 & 4.00 & 15.00 \\
\hline
\end{tabular}

\section{Pengujian Hipotesis}

Pengujian hipotesis dalam penelitian ini meliputi uji beda t-testi. Perhitungan analisa uji beda t-test dilakukandengan bantuan program SPSS 21. Adapun pengujian hipotesis langkah-langkah uji hipotesis dapat dijelaskan sebagai berikut:

\section{Hipotesis}

H0 : Tidak ada perbedaan kemampuan berfikir kritis mahasiswa biologi yang menggunaan e-learning dengan menggunakan pembelajaran konvensional pada konsep ekosistemn. 
Ha : Ada perbedaan kemampuan berfikir kritis mahasiswa biologi yang menggunaan e-learning dengan menggunakan pembelajaran konvensional pada konsep ekosistem.
Berdasarkan hasil uji beda t-test untuk mengetahui perbedaan kedua pendekatan hasil belajar tersaji secara ringkas pada Tabel 2

Tabel.2

Rangkuman Uji Beda t-test Kemampuan Berfikir Kritis Mahasiswa Biolog

\begin{tabular}{llrrrr}
\hline & \multicolumn{6}{c}{ Group Statistics } \\
\hline \multirow{2}{*}{ NILAI_BK } & KELAS & N & \multicolumn{1}{c}{ Mean } & Std. Deviation & \multicolumn{1}{c}{ Std. Error Mean } \\
& KELAS A & 30 & 10.0167 & 3.06955 & 56042 \\
& KELAS C & 30 & 9.8500 & 2.96284 & .54094 \\
\hline
\end{tabular}

\begin{tabular}{|c|c|c|c|c|c|c|c|c|c|c|}
\hline \multicolumn{11}{|c|}{ Independent Samples Test } \\
\hline & & \multicolumn{2}{|c|}{$\begin{array}{l}\text { Levene's Test } \\
\text { for Equality of } \\
\text { Variances }\end{array}$} & \multicolumn{7}{|c|}{ t-test for Equality of Means } \\
\hline & & \multirow[t]{2}{*}{$\mathrm{F}$} & \multirow[t]{2}{*}{ Sig. } & \multirow[t]{2}{*}{$\mathrm{t}$} & \multirow[t]{2}{*}{ df } & \multirow[t]{2}{*}{$\begin{array}{l}\text { Sig. } \\
(2- \\
\text { tailed })\end{array}$} & \multirow[t]{2}{*}{$\begin{array}{c}\text { Mean } \\
\text { Differenc } \\
\text { e }\end{array}$} & \multirow[t]{2}{*}{$\begin{array}{l}\text { Std. Error } \\
\text { Differenc } \\
\mathrm{e}\end{array}$} & \multicolumn{2}{|c|}{$\begin{array}{l}\text { 95\% Confidence } \\
\text { Interval of the } \\
\text { Difference }\end{array}$} \\
\hline & & & & & & & & & Lower & Upper \\
\hline \multirow{2}{*}{$\begin{array}{l}\text { NILAI } \\
\text { _HB }\end{array}$} & $\begin{array}{l}\text { Equal variances } \\
\text { assumed }\end{array}$ & .114 & .737 & .214 & 58 & .831 & .16667 & .77890 & -1.3924 & 1.72581 \\
\hline & $\begin{array}{l}\text { Equal variances } \\
\text { not assumed }\end{array}$ & & & .214 & 57.928 & .831 & .16667 & .77890 & -1.3925 & 1.72585 \\
\hline
\end{tabular}

Berdasarkan hasil pada keluaran SPSS 21, Independent Samples Tes kolom t-test for Equality of Means, skore sig. (2 tailed) sebesar 0,737. Berdasarkan kriteria, bila nilai sig. (2 tailed) > 0,05 maka Ho diterima. Hal ini berarti tidak terdapat perbedaan yang signifikan kemampuan berpikir kritis mahasiswa yang proses pembelajarannya menggunakan elearning dan pembelajaran konvensional pada konsep ekosistem.

Dalam penelitian ini, kemampuan berfikir kritis mahasiswa yang diberi perlakuan yang berbeda tenyata memberikan hasil yang sama, hal ini dikarenakan baik ada atau tidak adanya dosen dikelas ternyata proses diskusi tentang materi ini masih bisa dilakukan secara maksimal, seperti pada e- learning ada kolom chatting yang bisa diikuti oleh seluruh mahasiswa yang ingin berdiskusi baik dengan dosen atau mahasiswa lainnya, hal ini memberikan makna yang sama seperti kegiatan diskusi yang biasa dilakukan pada kelas konvensional.

\section{SIMPULAN}

Berdasarkan penelitian, pengolahan data, dan pengujian hipotesis, maka penulis berkesimpulan bahwa: tidak terdapat perbedaan hasil belajar mahasiswa biologi yang menggunaan e-learning dengan konvensional pada konsep sistem pencernaan manusia. Pembelajaran e-learning dan konvensional bisa menjadi salah satu rujukan pembelajaran yang bisa digunakan oleh dosen/guru untuk 
meningkatkan hasil belajar, Purbo. 2002. Flash Design dan pembelajaran e-learning bisa Animasi Web. Jakarta: Elex Media digunakan sebagai pembelajaran alternatif apabila dosen/guru tidak dapat bertatap muka dengan mahasiswa dikelas, dikarenakan memberikan pengaruh yang sama terhadap hasil belajar.

\section{DAFTAR PUSTAKA}

Anderso. Lorin W.; Krathwohl, David $\mathrm{R}$; Arisanian, Peter W.;

Cruikshank; Kathleen A.; Mayer, Richard E.; Paul R.; Raths, James; dan Wittrock, Merlin C. (ed) (2001). A Taxonomy for Learning Teaching and Assessing A revision of Bloom's Taxonomy of Educational Objectivities. Abridged Edition. New York : Longman Inc.

Djamarah, Bahri Syaiful dan Zain, Aswan. 2010. Strategi Belajar Mengajar. Jakarta: Rineka Cipta. Muhibbin Syah. (2003). Psikologi Belajar. Jakarta: PT. Raja Grafindo Persada.

Nazir, Moh. 2005. Metode Penelitian. Jakarta: Ghalia Indonesia. Komputindo.

Renaldo, Ferri. 2009. Moodle dan Fitur-fiturnya. [online] tersedia di: http://ilmukomputer.org/wpcontents/ uploads/20099/02/ferrifiturmoodle.pdf. (26/110/2016).

Ruseffendi. 2010. Dasar-dasar Penelitian Pendidikan dan Bidang Non Eksakta Lainnya. Bandung : Tarsito.

Sugiyono. 2012. Metode Penelitian Kuantitatif, kulaitatif dan $R \& D$, Bandung : Alpfabeta

Sukari.2011. Learning Management System ElearningPro. [online] tersedia di: http://www.pasweb.com/LMS/Lear ningManagementSystemElearningP roPortalPaketAplikasiSekolahPASb erbasisWeb.htm. (20/10/2016)

Suwartono. 2014. Dasar-Dasar Metodologi Penelitian. Yogyakarta: Andi Yogyakarta

Wahono, R.S. 2009. System e-learning berbasis model motivasi komunitas [online] tersedia di: http://ilmukomputer.org/wpcontents/uploads/2007/10/romimodelmotivasikomunitas3oktober2007.zip. (26/10/2016) 